\title{
Recall and response of smokers and recent quitters to the Australian National Tobacco Campaign
}

\author{
M Wakefield, J Freeman, R Donovan
}

Tobacco Control 2003;12(Suppl II):ii 15-ii22

See end of article for authors' affiliations

....................

For correspondence: $M$ Wakefield, Director, Centre for Behavioural Research in Cancer, The Cancer Council Victoria, 1 Rathdowne Street, Carlton Victoria 3053,

Australia;

melanie.wakefield@

cancervic.org.au
Objective: To track national population indices of recall and response among smokers and recent quitters to an ongoing national televised anti-smoking campaign in Australia.

Method: National cross sectional population telephone surveys of adults.

Main outcome measures: Unprompted recall of advertising; recognition of advertising; campaign attributed encouragement to quit or stay quit; unprompted awareness of smoking related health effects; new learning about smoking and health; and agreement with campaign related attitudes.

Results: Campaign advertising continued to be highly memorable over the period of study, with $88 \%$ having confirmed recognition in 2000. Campaign advertising was consistently thought by half of smokers who had seen it to make them more likely to quit (49\% in 2000). Specific changes between surveys in unprompted awareness of smoking related health effects, new learning about smoking and health, and agreement with campaign related attitudes were observed in relation to the main messages of the advertisements, which were time sensitive according to the year of launch of the advert. The "artery" advertisement was associated with the largest and most consistent positive change in all of these parameters. The proportion of respondents who disagreed that the dangers of smoking had been exaggerated increased significantly from 59\% in May 1997 to 68\% in November 2000.

Conclusion: A national campaign using graphic advertising to emphasise the health risks of smoking can make significant population wide contributions to improving new learning about smoking damage and positively influence attitudes about smoking risks.
R search from Australia was among the first to demonstrate that anti-smoking advertising could positively change smoking behaviour and reduce smoking prevalence. ${ }^{1-2}$ Reviews of the literature have generally concluded that anti-smoking media campaigns have an important role to play as part of a comprehensive tobacco control programme..$^{3-5}$ Although much of the literature has been focused on the effects of anti-smoking advertising among youth, ${ }^{6}$ evaluation conducted to monitor outcomes of long standing statewide comprehensive tobacco control programmes in California ${ }^{7-8}$ and Massachusetts ${ }^{9}$ and a recent controlled trial of a television anti-smoking advertising campaign in Britain $^{10}$ provide further confirmation that anti-smoking advertising can be effective in reducing smoking among adults.

However, there is continuing debate about the kind of advertising most reliably associated with positive changes in smoking habits, with some arguing that adverts that graphically portray the health effects of smoking are discounted as unconvincing by smokers. ${ }^{11-12}$ Others, in contrast, suggest that this kind of advertising can confront and engage smokers in a way that increases the likelihood of smoking cessation. ${ }^{13-14}$ Fear or threat appeals have great potential for stimulating behavioural change if they are used in conjunction with techniques designed to promote confidence in behavioural change. ${ }^{15-16}$ This paper seeks to provide an overview of the responses of smokers to a national antismoking advertising campaign in Australia, which used graphic fear based messages as a dominant part of its communication strategy.

The Australian National Tobacco Campaign (NTC) was launched in June 1997 as a cooperative partnership between Australian Federal, State, and Territory governments and interested non-government organisations. The campaign was primarily targeted at 18-40 year old smokers with the message that "every cigarette is doing you damage". The advertising strategy, outlined in detail elsewhere, ${ }^{13}{ }^{17}$ aimed to translate the scientific knowledge about smoking risks into "felt" experience, rather than cognitive appreciation of risk. Briefly, each advertisement brought smokers some new news about smoking, or portrayed old news in a new way. Each message was framed to maximise the effect on behaviour by using several devices, including: (a) an emphasis on relatively certain effects, than less probable effects-thus an emphasis on ongoing damage, rather than long term clinical outcomes; (b) the use of smoker moments-awkward situations in which smokers often find themselves-to engage the smoker and convey empathy for their situation; and (c) the use of graphics designed to produce a strong visceral response in the viewer. To increase the likelihood of the audience taking action toward quitting, each advertisement was tagged with the number of the Quitline telephone service, a free cessation advice service for smokers. In addition, one specific advert encouraged smokers to call the Quitline for advice and information on how to quit.

Since 1997, six television advertisements have graphically featured the health damage done by smoking. The health effects adverts included: "artery" — every cigarette contributes to clogged arteries; "lung"- - every cigarette contributes to destruction of air sacs in the lungs; "tumour" - every cigarette increases the likelihood of genetic damage to lung cells, which could lead to lung cancer; "brain"-every cigarette increases the risk of tiny blood vessels bursting in the brain, which could lead to a stroke; "tar"- - every cigarette contributes to the amount of tar in the lungs; "eye" - every cigarette increases the risk of rupture of tiny blood vessels in the eyes, which could ultimately lead to blindness.

During the first six months of the campaign from June to December 1997 (designated phase one for the purposes of evaluation), a total of around Australian \$4.54 million (the equivalent of Australian $\$ 0.48$ cents per capita per annum) was spent by the Australian Federal, State, and Territory governments to broadcast three main advertisements (lung,

Abbreviations: NTC, National Tobacco Campaign; TARPs, target audience rating points 


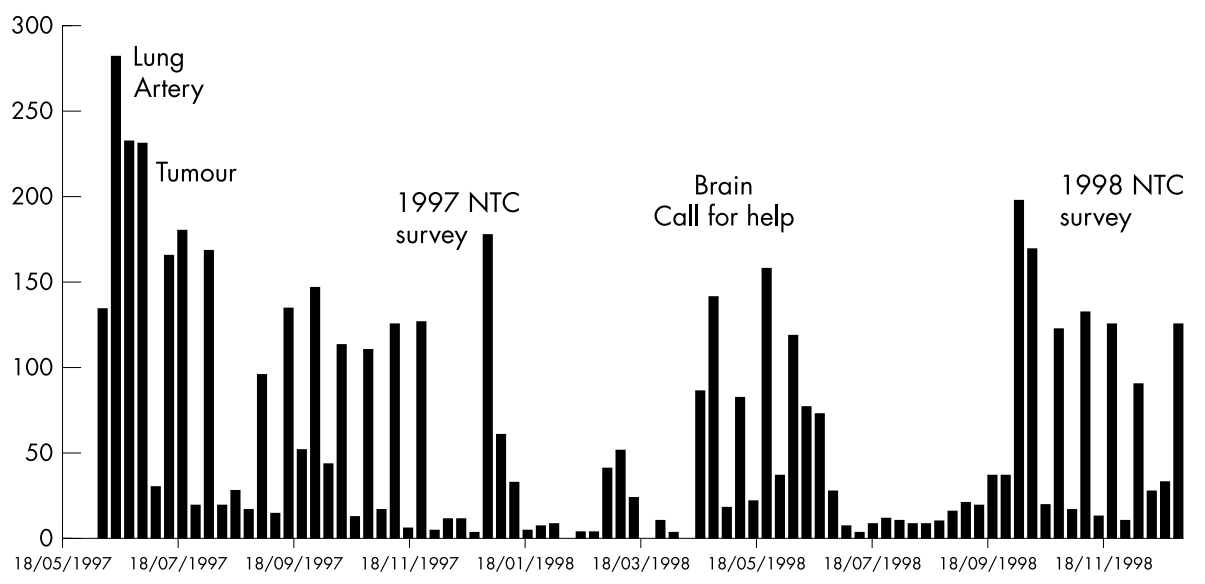

Figure 1 National target audience rating points (TARPs) for National Tobacco Campaign (NTC) television advertisements $1997-1998$ (phases one and two), target group 18-40 years. Advertisements most prominent in the peaks of weekly television TARPs, and timing of evaluation surveys, are indicated.

artery, and tumour). During 1998 the campaign continued with what was considered to be a maintenance phase budget with Commonwealth and State government media expenditure equivalent to Australian $\$ 0.32$ cents per capita per annum. From January to December 1998 (designated as phase two), the brain advertisement was added and an advertisement modelling the behaviour of calling the Quitline ("call for help") was introduced. Phase three of the campaign for the purposes of this evaluation spanned January 1999 to December 2000 and included two new health effects advertisements (tar and eye), launched in mid 2000. Media expenditure by governments over this period equated to Australian $\$ 0.27$ cents per capita per annum.

Consistent with the media expenditure, figs 1 and 2 shows that the estimated exposure of the target group to the advertising varied over the period. Overall, the initial period of advertising from May to December 1997 in phase one achieved an average of 88.4 target audience rating points (TARPs) per week, whereas phase two (from January 1998 to December 1998) achieved 46.5 per week, and phase three (from January 1999 to December 2000) averaged 52.9 per week. A TARP is a standard measure of the weekly volume of television advertising designed to reach a particular target audience. A weekly TARP value of 0.884 TARPs per week means that the average 18-40 year old saw one of the NTC adverts 884 times during the course of a week.

Evaluating a campaign to which an entire nation is exposed is a complex task. Because the whole population was exposed to the campaign, there was no unexposed group who could be used as a comparison. There are difficulties in relating any change in smoking prevalence, or lack of it, to the effect of the campaign. If a decline was observed, reductions in prevalence may have occurred even in the absence of the campaign, or if there was no change it may mean that the campaign corrected an upward trend that would have prevailed had the campaign not been run. In the meantime there are more proximal early indicators of whether a campaign may be working in the manner intended.

In order to assess whether a campaign is likely to influence smoking prevalence, a number of conditions need to be met. Firstly, smokers need to have seen the campaign and remember it. Secondly, they must appraise the information presented in the campaign as believable and personally relevant, and it must make them think about quitting. These variables are amenable to direct measurement because we are able to ask smokers about their specific thoughts and behaviours in relation to the television advertisements, the campaign slogan, and the overall campaign. In addition to this, if we are to expect a change in smoking prevalence, we must look for evidence that there have been changes in health beliefs and attitudes. These variables are less able to be directly linked to the campaign as there will be other factors that influence change in these parameters, so that we must impute their relationship with campaign exposure. The evaluation was designed to help make attributions as to whether the campaign may be linked to changes in these variables.

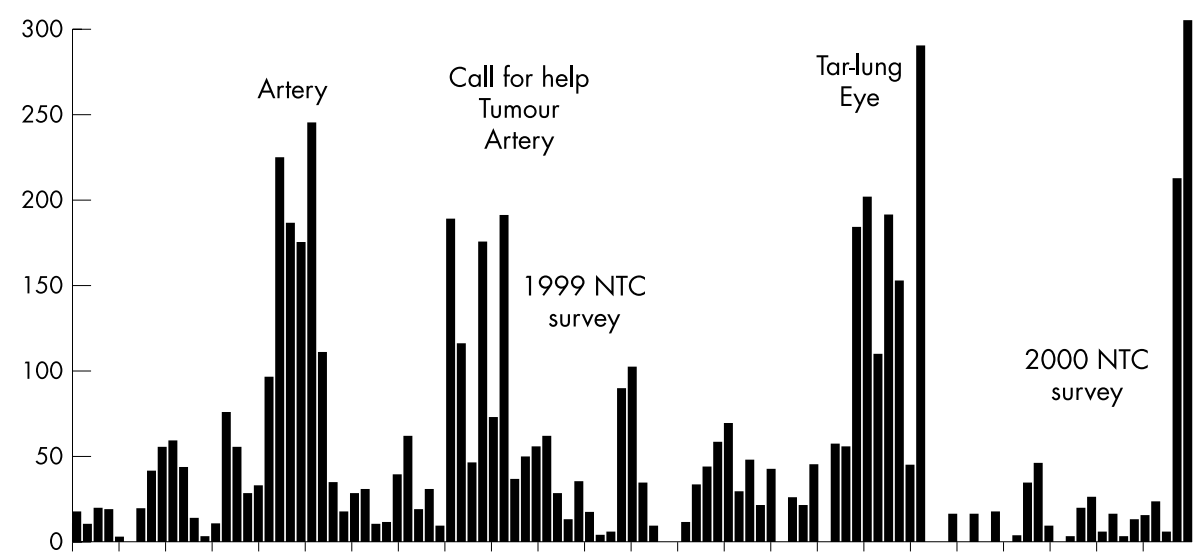

Figure 2 National target audience rating points (TARPs) for National Tobacco Campaign (NTC) television advertisements $1999-2000$ (phase three), target group 16-40 years. Advertisements most prominent in the peaks of weekly television TARPs, and timing of evaluation surveys, are indicated. 
Table 1 Sample size of benchmark and follow up surveys

\begin{tabular}{|c|c|c|c|c|c|}
\hline & $\begin{array}{l}\text { Benchmark } \\
\text { May } 1997\end{array}$ & $\begin{array}{l}\text { Follow up } 1 \\
\text { Nov } 1997\end{array}$ & $\begin{array}{l}\text { Follow up } 2 \\
\text { Nov } 1998\end{array}$ & $\begin{array}{l}\text { Follow up } 3 \\
\text { Nov } 1999\end{array}$ & $\begin{array}{l}\text { Follow up } 4 \\
\text { Nov } 2000\end{array}$ \\
\hline Informants aged $\geqslant 18$ years & 6632 & 17572 & 11153 & 12246 & 13742 \\
\hline Total household enumeration aged $\geqslant 18$ years & 13807 & 36538 & 23319 & 25147 & 29267 \\
\hline Survey respondents $18-40$ years & 1979 & 4197 & 2289 & 2277 & 2308 \\
\hline Nonsmoker respondents & 781 & 1191 & 628 & 645 & 613 \\
\hline Smoker and recent quitter respondents & 1192 & 2981 & 1646 & 1611 & 1675 \\
\hline
\end{tabular}

The aim of this paper is to provide an overview of change among smokers and those who have recently quit smoking in relation to anti-smoking advertising recall and campaign advertising recognition, campaign attributed encouragement to quit or stay quit, new learning, and campaign related attitudes about smoking and health.

\section{METHOD}

\section{Sample population}

The main evaluative tool for the Australian NTC was a series of national cross sectional surveys. The benchmark survey was undertaken in May 1997, and subsequent surveys were undertaken in November 1997, 1998, 1999, and 2000. ${ }^{18-20}$

The evaluation surveys were commissioned by the Australian Commonwealth Department of Health and Aged Care and conducted by Roy Morgan Research. Each of the surveys was conducted by telephone and used the electronic White Pages as the sampling frame. Households were randomly selected from the electronic White Pages. An approximately equal number of respondents was selected from each of Australia's six States (the Australian Capital Territory was included with New South Wales and the Northern Territory was included with South Australia), whereby $75 \%$ of the sample respondents were smokers (those who smoked on a weekly basis) or recent quitters (defined as those who had, over the past year, stopped smoking cigarettes on a weekly basis), and the remainder were other ex-smokers and nonsmokers. The aim was to randomly generate a reasonably large number of smokers and recent quitters from each State using a standard method in order to track their responses to the campaign, rather than to estimate the proportion of the population who recalled or responded to the campaign. Of those households contacted and eligible, $45 \%$ responded, with no substantive or significant differences in response rate between years.

Once the interviewer made contact with a person in the household aged $\geqslant 18$ years (the informant), that person was asked unprompted questions about recall of health advertising. Following these questions the interviewer asked the informant to describe the number of adults residing at the household and, for each, their age, sex, and whether they were a smoker or recent quitter. Only those aged 18-40 years were eligible to progress as respondents to the complete interview. Up to two smokers or recent quitters and one nonsmoker per household could be interviewed, and where there were more household members fitting this description a random procedure was employed to select them. Where these selected respondents were not at home when the interviewer first called, call backs were made in an attempt to interview the selected person(s). Informants and selected respondents were aware the survey was about health, but not tobacco in particular, when they commenced the interview.

Table 1 shows the number of people aged $\geqslant 18$ years who comprised the informant, enumeration, and respondent surveys. People aged $\geqslant 18$ years who answered the telephone comprised the informant sample. The informants reported on all of the residents in their household, aged $\geqslant 18$ years, known as the enumeration sample. For the respondent sample, only those aged 18-40 years in the household were eligible to participate as individual respondents. Respondents were categorised as smokers, recent quitters, and nonsmokers.

\section{Questionnaire administration}

The enumeration survey initially identified the smoking status of all adults in the household and determined subject selection. The telephone questionnaire asked in an unprompted fashion about awareness of advertising about health. This was asked of all informants and also of new respondents. To measure unprompted recall of the campaign, respondents were asked: "During the past three months, have you seen or heard any advertising campaign on TV, radio, in the newspaper, or anywhere else encouraging people to do things to improve their health?" If respondents said they had, they were then asked: "What was the advertising campaign(s) about?" If smoking issues were mentioned, interviewers then asked respondents to describe what they recalled. Unprompted recall is a function of the amount and recency of advertising weight, as well as the attention getting features of advertisements.

Respondents were asked unprompted questions to measure their ability to recall illnesses caused by smoking. In the first question, respondents were asked "In your opinion, are there any illnesses caused by smoking?" Those respondents who answered in the affirmative were asked to indicate which illnesses were so caused, and the interviewer noted the first mention and then asked the respondent for any other illnesses that were thought to be caused by smoking. Using the same question method, respondents were further asked in an unprompted fashion about whether they thought there were any forms of damage to the body caused by smoking. These two questions were rotated in the questionnaire to minimise order effects. These questions assessed "top of mind" awareness of health damage and diseases that featured in campaign related advertising, reflecting the prominence of this information in memory.

To assess new learning about smoking, respondents were asked: "During the past six months, have you learned anything new about the effects of smoking cigarettes on health?" If so, they were asked to describe what they had learned. All respondents were asked about agreement or disagreement with a range of opinion statements relating to smoking and health. All respondents were then asked about their cigarette smoking to confirm categorisation of respondents into smokers, recent quitters, and others. Smokers and recent quitters were asked to decide on the truthfulness of several statements about key campaign related attitudes. Their response to these statements was used as another measure of the degree to which beliefs and attitudes about smoking and health had changed over the campaign period. In the follow up surveys, prompted recognition of the campaign was assessed by briefly describing the common characteristics of the television advertisements, which included "following the smoke down a smoker's throat and into their lungs, after which we see and hear a demonstration of the effects smoking has on the body. After this, we pass back through the smoker's throat as they exhale and on the screen appears a telephone 
Table 2 Demographic characteristics of smoker and recent quitter respondents

\begin{tabular}{|c|c|c|c|c|c|}
\hline & $\begin{array}{l}\text { Benchmark } \\
\text { May 1997 } \\
(n=1192)\end{array}$ & $\begin{array}{l}\text { Follow up } 1 \\
\text { Nov 1997 } \\
(n=2981)\end{array}$ & $\begin{array}{l}\text { Follow up } 2 \\
\text { Nov 1998 } \\
(n=1646)\end{array}$ & $\begin{array}{l}\text { Follow up } 3 \\
\text { Nov 1999 } \\
(n=1611)\end{array}$ & $\begin{array}{l}\text { Follow up } 4 \\
\text { Nov 2000 } \\
(n=1675)\end{array}$ \\
\hline \multicolumn{6}{|l|}{ Sex } \\
\hline Male & $47 \%$ & $48 \%$ & $44 \%$ & $47 \%$ & $46 \%$ \\
\hline Female & $53 \%$ & $52 \%$ & $56 \%$ & $53 \%$ & $54 \%$ \\
\hline \multicolumn{6}{|l|}{ Age } \\
\hline $18-29$ years & $50 \%$ & $46 \%$ & $46 \%$ & $45 \%$ & $48 \%$ \\
\hline $30-40$ years & $50 \%$ & $54 \%$ & $54 \%$ & $55 \%$ & $52 \%$ \\
\hline \multicolumn{6}{|l|}{ Educational status } \\
\hline Completed at least some secondary schooling & $63 \%$ & $65 \%$ & $65 \%$ & $60 \%$ & $61 \%$ \\
\hline Completed at least some tertiary & $37 \%$ & $35 \%$ & $35 \%$ & $40 \%$ & $40 \%$ \\
\hline \multicolumn{6}{|l|}{ Work status } \\
\hline Working & $75 \%$ & $74 \%$ & $71 \%$ & $73 \%$ & $73 \%$ \\
\hline Retired/pensioner & $2 \%$ & $3 \%$ & $2 \%$ & $3 \%$ & $4 \%$ \\
\hline Student & $6 \%$ & $6 \%$ & $6 \%$ & $6 \%$ & $6 \%$ \\
\hline Home duties & $11 \%$ & $10 \%$ & $14 \%$ & $13 \%$ & $11 \%$ \\
\hline Unemployed & $6 \%$ & $6 \%$ & $6 \%$ & $5 \%$ & $6 \%$ \\
\hline \multicolumn{6}{|l|}{ Occupational status } \\
\hline Blue collar & $45 \%$ & $45 \%$ & $52 \%$ & $48 \%$ & $45 \%$ \\
\hline White collar & $55 \%$ & $55 \%$ & $48 \%$ & $52 \%$ & $55 \%$ \\
\hline \multicolumn{6}{|l|}{ Language spoken at home } \\
\hline English & $96 \%$ & $97 \%$ & $97 \%$ & $96 \%$ & $97 \%$ \\
\hline Other & $4 \%$ & $3 \%$ & $3 \%$ & $4 \%$ & $3 \%$ \\
\hline
\end{tabular}

number and the campaign slogan "every cigarette is doing you damage". Respondents were then asked whether they had read, seen, or heard any advertising from the campaign and their appraisal of it. Smokers who recognised the campaign advertising were asked if it had made them more or less likely to quit smoking or had made no difference. Recent quitters were asked whether such advertising helped them to stay quit, made it more difficult to stay quit, or had no effect.

Demographic information obtained for each household member included age and sex, but, for those smokers and recent quitters who progressed to a full interview, additional information was collected, including level of educational attainment, language spoken at home, employment status, and respondent's and main income earner's occupational status. The questionnaires were designed so that answers to unprompted questions would not be biased by preceding questions. Rotation of some questions and response options within questions was used to minimise order effects.

This paper focuses on the responses from smokers and recent quitters in the respondent sample. Nonsmoker responses to campaign related questions are not reported, but are available elsewhere. ${ }^{18-20}$ Table 2 shows the demographic characteristics of smokers and recent quitter respondents for each survey. In general, there were no systematic differences in the demographic characteristics of survey respondents over time.

\section{Statistical methods and presentation of data}

Respondent survey data were weighted by State in order to better reflect a population of Australian smokers and recent quitters. Each survey sample of smokers and recent quitters was analysed using the SPSS package (Version II) to identify significant changes across survey years. Relative changes in proportions over time were analysed using logistic regression, with time modelled as a categorical variable. The $p$ value of the odds ratio was used to assess whether changes between years were significant. Information on $95 \%$ confidence intervals (95\% CIs) is given in the Appendix, for readers wishing further information on the variability of point estimates (see Appendix). To assess whether changes over time were related to changes in the sociodemographic composition (age, sex, educational attainment, work status, occupational status) of smokers and recent quitters, we used $\chi^{2}$ tests. In all cases, statistical test results showed that there were no significant changes in sample composition that would have accounted for change over time, thereby eliminating the need to adjust for change in sample composition across survey years.

\section{RESULTS}

\section{Campaign recall and recognition}

Table 3 shows that, after an initial significant increase from the benchmark to the first follow up survey associated with the commencement of the NTC, there was a gradual and significant drift downwards in the proportion of respondents who, unprompted, recalled seeing any health advertising in the three months prior to the survey. This result should be interpreted with caution because it is dependent upon the overall impact of other concurrent health related advertising, about which we do not have data. Unprompted recall of anti tobacco advertising also showed a significant increase from benchmark (25-46\% in first follow up), followed by significant gradual decline, although remaining significantly above the benchmark level. This decline is consistent with lower TARPs in successive phases of the campaign.

Prompted recognition of campaign advertising, which measures exposure to the campaign advertising (and hence successive follow ups represent a cumulative exposure measure) was maintained at around $90 \%$ over each follow up survey year

\section{Campaign attributed encouragement to quit or stay quit}

Table 4 shows that approximately half of smokers who recognised the campaign advertising reported that the adverts had made them more likely to quit. The percentage of smokers making this attribution did not vary over time. For recent quitters, $60 \%$ reported the campaign advertising made them more likely to stay quit, but there was a significant decline such that in 2000, 44\% expressed this view. After 1997, a correspondingly greater percentage of recent quitters thought that the advertising had no effect on them, being 53\% in 2000 .

\section{Change in campaign related beliefs and attitudes}

Table 5 shows the smoking caused illnesses and damage most salient in the minds of smokers and recent quitters. The salience of any artery illness or damage increased significantly between the benchmark and first follow up surveys, but declined between the 1999 and 2000 surveys. Mention of any 
Table 3 Unprompted recall and recognition of anti tobacco advertising among smoker and recent quitter respondents

\begin{tabular}{|c|c|c|c|c|c|}
\hline & $\begin{array}{l}\text { Benchmark } \\
\text { May 1997 } \\
(n=1192)\end{array}$ & $\begin{array}{l}\text { Follow up } 1 \\
\text { Nov 1997 } \\
(\mathrm{n}=2981)\end{array}$ & $\begin{array}{l}\text { Follow up } 2 \\
\text { Nov 1998 } \\
(\mathrm{n}=1647)\end{array}$ & $\begin{array}{l}\text { Follow up } 3 \\
\text { Nov } 1999 \\
(n=1612)\end{array}$ & $\begin{array}{l}\text { Follow up } 4 \\
\text { Nov 2000 } \\
(n=1675)\end{array}$ \\
\hline Seen any health advertising in the past 3 months (\% yes) & $74 \%$ & $82 \% *$ & $81 \%$ & $79 \%$ & $77 \% \dagger \ddagger$ \\
\hline Unprompted recall of anti tobacco advertising & $25 \%$ & $46 \% *$ & $42 \%$ & $36 \%$ & $35 \%+\S$ \\
\hline Prompted recognition of campaign advertising: (\%yes) & NA & $87 \%$ & $87 \%$ & $91 \%$ & $88 \%$ I \\
\hline 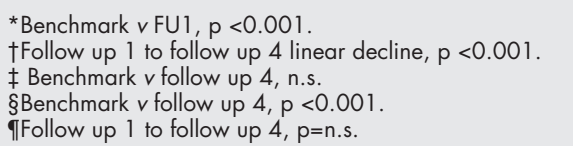 & & & & & \\
\hline
\end{tabular}

lung illness or damage did not change from its already high level of $80 \%$ at the benchmark survey. There was a significant increase in mentions of brain disease from 3\% in 1997 to $12 \%$ in 1998, coincident with the launch of the brain advert earlier in 1998. No eyesight or lung category changes were detected coincident with the launch of the eye and tar adverts in 2000, although there may have been limitations on tar's impact by the possible ceiling effect of the "any lung damage" category.

Table 6 shows a significant increase between benchmark and the first follow up survey in the proportion of smokers and recent quitters combined who reported learning something new in the past six months about the effects of cigarette smoking. The percentage declined in 1999 and 2000, but remained higher than benchmark.

Between the benchmark and first follow up survey, new learning about clogged arteries, lungs like sponges, and every cigarette is doing you damage, showed significant increases. These gains were maintained over time, although there was a trend towards reduced new learning about these issues. This pattern may be related to reduced television exposure from a lower level of television buy, the saturation effects of new knowledge about these issues, or a combination of the two. The launch of the brain advert in 1998 was associated with an apparent peak in new learning pertaining to strokes or clots in the brain, but causal interpretation is limited by the lack of baseline data. Following the launch of the eye advertisement in mid-2000, there was a significant increase in the proportion of respondents reporting new knowledge concerning the effects of smoking on loss of eyesight, from $2 \%$ to $11 \%$.

Several generic questions were asked to ascertain respondents' opinions about smoking information provided in the advertising campaigns. Firstly, respondents were asked whether they thought the dangers of smoking had been exaggerated. Table 5 shows that between the benchmark and first follow up survey, there was a significant increase in the percentage of respondents who disagreed with this statement.
Between the benchmark survey and the 2000 survey, this percentage continued to increase significantly, such that in 2000 $68 \%$ of smokers and recent quitters disagreed that the dangers of smoking had been exaggerated.

There was a significant linear increase from the benchmark survey in the percentage of respondents who disagreed with propositions that “smoking can't be all that bad because many people smoke all their lives and live to a ripe old age" and that "the occasional cigarette doesn't cause any harm". These statements represent key misperceptions that the campaign has tried to correct with its emphasis on every cigarette doing damage.

Table 5 also shows the proportion of respondents agreeing with key statements that reflected attitudes to the campaign. The proportion of respondents agreeing that "every cigarette is doing you damage" increased between the benchmark and first follow up survey and was subsequently maintained to the 2000 survey. Agreement with the statement pertaining to one of the early campaign adverts, namely artery (smoking blocks up arteries with fatty deposits), increased significantly between the benchmark and first follow up and was maintained to the 2000 survey. There was also a significant increase between the benchmark and first follow up survey in the proportion agreeing that smoking causes damage to the genes in lung cells, which was maintained up until the 2000 survey. The high proportion of smokers and recent quitters believing that smoking causes decay in the lungs was maintained over the campaign, with these rates of agreement leaving little room for improvement.

In 1998, statements that smoking causes strokes and smoking causes blood clots in the brain were introduced to track potential effects of the launch of the brain advert in 1998. There was a significant increase between 1999 and 2000 in the proportion of respondents who agreed that smoking causes strokes, but no change in the proportion indicating that smoking causes blood clots in the brain between 1998 and

\begin{tabular}{|c|c|c|c|c|}
\hline & $\begin{array}{l}\text { Follow up } 1 \\
\text { Nov 1997 } \\
(\mathrm{n}=2981)\end{array}$ & $\begin{array}{l}\text { Follow up } 2 \\
\text { Nov 1998 } \\
(n=1647)\end{array}$ & $\begin{array}{l}\text { Follow up } 3 \\
\text { Nov 1999 } \\
(n=1612)\end{array}$ & $\begin{array}{l}\text { Follow up } 4 \\
\text { Nov 2000 } \\
(n=1675)\end{array}$ \\
\hline Smokers & $(n=2312)$ & $(n=1301)$ & $(n=1271)$ & $(n=1320)$ \\
\hline More likely to quit & $51 \%$ & $50 \%$ & $47 \%$ & $49 \% *$ \\
\hline No difference & $45 \%$ & $46 \%$ & $49 \%$ & $47 \%$ \\
\hline Less likely to quit & $3 \%$ & $3 \%$ & $2 \%$ & $2 \%$ \\
\hline Can't say & $2 \%$ & $1 \%$ & $1 \%$ & $2 \%$ \\
\hline Quitters & $(n=289)$ & $(n=123)$ & $(n=192)$ & $(n=154)$ \\
\hline Helped to stay quit & $60 \%$ & $56 \%$ & $52 \%$ & $44 \% \dagger$ \\
\hline Had no effect & $35 \%$ & $40 \%$ & $43 \%$ & $53 \%$ \\
\hline Made it more difficult & $2 \%$ & $1 \%$ & $3 \%$ & $1 \%$ \\
\hline Can't say & $4 \%$ & $3 \%$ & $2 \%$ & $2 \%$ \\
\hline
\end{tabular}


Table 5 Unprompted awareness of illness and damage, level of agreement with opinion statements about smoking and health and campaign related attitudes among smoker and recent quitter respondents

\begin{tabular}{|c|c|c|c|c|c|}
\hline & $\begin{array}{l}\text { Benchmark } \\
\text { May 1997 } \\
(\mathrm{n}=1192)\end{array}$ & $\begin{array}{l}\text { Follow up } 1 \\
\text { Nov 1997 } \\
(n=2981)\end{array}$ & $\begin{array}{l}\text { Follow up } 2 \\
\text { Nov 1998 } \\
(n=1646)\end{array}$ & $\begin{array}{l}\text { Follow up } 3 \\
\text { Nov } 1999 \\
(n=1611)\end{array}$ & $\begin{array}{l}\text { Follow up } 4 \\
\text { Nov 2000 } \\
(n=1675)\end{array}$ \\
\hline \multicolumn{6}{|l|}{ Unprompted awareness } \\
\hline Any artery illness/damage & $26 \%$ & $32 \% *$ & $30 \%$ & $32 \%$ & $26 \% \dagger$ \\
\hline Any lung illness/damage & $80 \%$ & $79 \%$ & $79 \%$ & $80 \%$ & $80 \%$ \\
\hline Genetic/DNA damage & $1 \%$ & $2 \%$ & $2 \%$ & $2 \%$ & $1 \%$ \\
\hline Any brain disease & $4 \%$ & $3 \%$ & $12 \% \ddagger$ & $8 \%$ & $8 \%$ \\
\hline Eyesight damage & - & - & - & $<1 \%$ & $2 \%$ \\
\hline \multicolumn{6}{|l|}{ Unprompted awareness of illness and damage caused by smoking } \\
\hline The dangers of smoking have been exaggerated (\% disagree) & $59 \%$ & $64 \% *$ & $61 \%$ & $64 \%$ & $68 \% \S$ \\
\hline $\begin{array}{l}\text { Smoking can't be all that bad because many people smoke all their lives } \\
\text { and live to a ripe old age ( } \% \text { disagree) }\end{array}$ & $59 \%$ & $61 \%$ & $60 \%$ & $62 \%$ & $66 \%$ \\
\hline $\begin{array}{l}\text { Smoking the occasional cigarette doesn't cause any damage to your } \\
\text { health (\% disagree) }\end{array}$ & $50 \%$ & $57 \% *$ & $55 \%$ & $57 \%$ & $60 \% \S$ \\
\hline \multicolumn{6}{|l|}{ Campaign-related attitudes } \\
\hline $\begin{array}{l}\text { Which is nearest to the truth? "Every cigarette is doing you damage" } v \\
\text { "You have to smoke for several years": (\% Every cigarette is doing you } \\
\text { damage) }\end{array}$ & $75 \%$ & $82 \% *$ & $81 \%$ & $79 \%$ & $81 \% * *$ \\
\hline Smoking blocks up arteries with fatty deposits (\% true) & $54 \%$ & $83 \% *$ & $76 \%$ & $80 \%$ & $80 \%$ ** \\
\hline Smoking causes damage to the genes in lung cells ( $\%$ true) & $67 \%$ & $78 \% *$ & $70 \%$ & $73 \%$ & $70 \%$ \\
\hline Smoking causes decay in the lungs ( $\%$ true) & $93 \%$ & $95 \%$ & $94 \%$ & $95 \%$ & $95 \%$ \\
\hline Smoking causes strokes (\% true) & NA & NA & $77 \%$ & $77 \%$ & $82 \% \dagger †$ \\
\hline Smoking causes blood clots in the brain (\% true) & NA & NA & $71 \%$ & $68 \%$ & $72 \% \ddagger \ddagger$ \\
\hline Smoking causes eye damage ( $\%$ true) & NA & NA & NA & NA & $50 \%$ \\
\hline 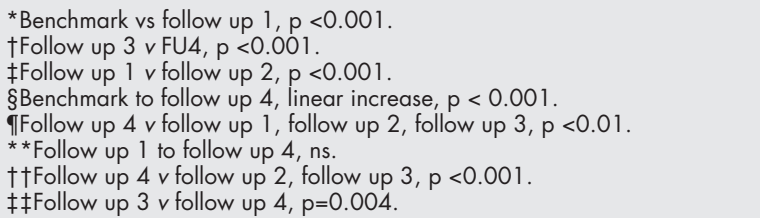 & & & & & \\
\hline
\end{tabular}

2000. It may be that gains occurred during 1998, but no benchmark comparison for these questions was available prior to the launch of this advert to assess this possibility. Similarly, no baseline measures were available prior to 2000, the launch year for the eye advert, to assess change in beliefs about whether smoking causes eye damage.

\section{DISCUSSION}

These results show that the NTC advertising was seen and recalled by substantial proportions of the target group and that the advertising continued to be highly memorable over the period of study. In later years, however, the advertising was less readily recalled as "top of mind". Figs 1 and 2 show that for the first and second follow up surveys, the survey data were collected during a period of intensive television advertising. The third follow up survey was conducted soon after such a period of advertising. However, the fourth follow up survey was conducted after three months of relatively low levels of television advertising. Because unprompted recall is affected by recency of exposure (the questionnaire asked about exposure in the past three months), the lower level of unprompted recall associated with the third and fourth follow up surveys is unsurprising. Thus, we conclude that declines in unprompted recall of advertising may be due to the lower amount of television buy prior to and during the third, and especially the fourth, follow up surveys.

Table 6 New learning about smoking and health in the past six months among smoker and recent quitter respondents

\begin{tabular}{|c|c|c|c|c|c|}
\hline & $\begin{array}{l}\text { Benchmark } \\
\text { May 1997 } \\
(=1192)\end{array}$ & $\begin{array}{l}\text { Follow up } 1 \\
\text { Nov 1997 } \\
(n=2981)\end{array}$ & $\begin{array}{l}\text { Follow up } 2 \\
\text { Nov 1998 } \\
(n=1646)\end{array}$ & $\begin{array}{l}\text { Follow up } 3 \\
\text { Nov 1999 } \\
(n=1611)\end{array}$ & $\begin{array}{l}\text { Follow up } 4 \\
\text { Nov } 2000 \\
(n=1675)\end{array}$ \\
\hline \multicolumn{6}{|c|}{$\begin{array}{l}\text { Learned anything new about the effects of smoking } \\
\text { cigarettes on health in past six months: }\end{array}$} \\
\hline Entire sample & $14 \%$ & $23 \% *$ & $23 \%$ & $19 \%$ & $18 \% \dagger$ \\
\hline \multicolumn{6}{|l|}{ What learnt: } \\
\hline Of those who learnt something new & $n=166$ & $n=670$ & $\mathrm{n}=374$ & $n=309$ & $\mathrm{n}=303$ \\
\hline Entire sample & $\mathrm{n}=1192$ & $n=2981$ & $\mathrm{n}=1646$ & $\mathrm{n}=1611$ & $\mathrm{n}=1675$ \\
\hline Clogged arteries & $7 \%(1 \%)$ & $36 \% *(8 \%)$ & $19 \%(4 \%)$ & $22 \%(4 \%)$ & $17 \%+\ddagger(3 \%)$ \\
\hline Lungs are like sponges & $7 \%(1 \%)$ & $20 \% *(4 \%)$ & $20 \%(4 \%)$ & $17 \%(3 \%)$ & $16 \%+\S(3 \%)$ \\
\hline Every cigarette is doing damage & $5 \%(1 \%)$ & $17 \% *(4 \%)$ & $10 \%(2 \%)$ & $11 \%(2 \%)$ & $7 \%+\uparrow(1 \%)$ \\
\hline How smoking causes lung cancer & $11 \%(2 \%)$ & $11 \%(3 \%)$ & $9 \%(2 \%)$ & $10 \%(2 \%)$ & $11 \%(2 \%)$ \\
\hline Causes strokes/clots in the brain & - & - & $25 \% * *(6 \%)$ & $7 \%(1 \%)$ & $4 \%(1 \%)$ \\
\hline Loss of eyesight & - & $<1 \%(<1 \%)$ & $1 \%(<1 \%)$ & $2 \%(<1 \%)$ & $11 \% \dagger \dagger(2 \%)$ \\
\hline \multicolumn{6}{|c|}{ 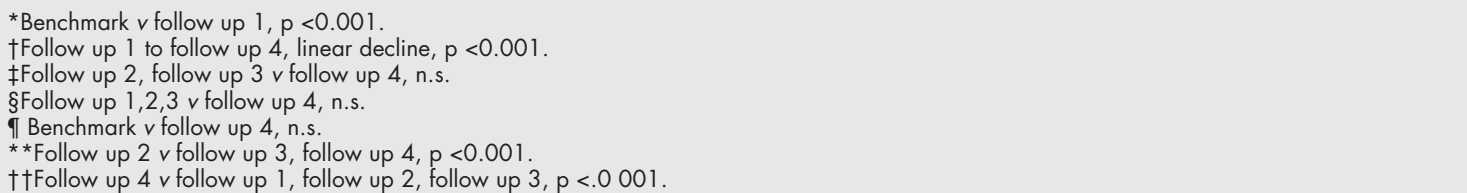 } \\
\hline
\end{tabular}


The campaign advertising was thought by around half of smokers to make them more likely to quit and this attribution was maintained over the entire period of study. For recent quitters, positive attributions were made early in the campaign in terms of the advertising helping them to stay quit, but there was evidence of a decline over the last two years of study.

In relation to the first three adverts launched at the campaign start in 1997, the pattern of results lent evidence for the artery advertisement as having most influenced smokers and recent quitters. This is consistent with the findings of Donovan et al, ${ }^{21}$ who used a weekly tracking survey methodology to compare more immediate response to different advertisements. Positive and statistically significant change occurred in relation to unprompted awareness of smoking related arterial damage, new learning about the effects of smoking on clogged arteries, and attitudes about whether smoking blocks up arteries with fatty deposits. These effects were most pronounced when comparing benchmark survey results with those from the first follow up survey, with some regression apparent in later survey years.

New learning about lungs being like sponges (referring to the lung advert) was also evident after the campaign launch, but measures of unprompted awareness and agreement with belief statements about smoking related lung damage showed no change, perhaps because baseline measures of these indices were already high, limiting the ability to detect further improvements. Agreement with belief statements about smoking causing damage to the genes in lung cells (referring to the tumour advert) also increased significantly between benchmark and the first follow up survey, and these gains were maintained over the period of study. However, gains in unprompted awareness and new learning about this issue were not detected.

There was some evidence that the brain advert launched in 1998 was associated with a peak in unprompted awareness that smoking was related to any brain disease, and to new learning about smoking causing strokes or blood clots in the brain. Confident interpretation of this latter finding was limited by lack of comparison data from survey years prior to 1998, although these data are consistent with tracking data showing that the stroke advert execution had considerable impact. ${ }^{21}$ Finally, we found a significant increase in new learning about smoking causing eyesight damage in 2000 compared with previous years, consistent with the eye advert being launched in 2000. Specific effects were not detected for the tar advert, although this may have been compromised by its similarity with the lung advert and the difficulty of detecting further improvement in measures pertaining to lung damage. Overall, although the different adverts appeared to have had a differential impact, and there were substantial variations in advertising weight throughout the phases, the campaign advertising had a significant and substantial impact on measures that are consistent with the new news and old news in a new way content of the advertising.

Over the course of the study, the overall advertising strategy, using graphic advertisements emphasising the negative health effects of smoking as recommended in Donovan's guidelines for public health advertising, ${ }^{22}$ continued to be convincing and believable to smokers and recent quitters. The significant increase over time in the percentage of smokers and recent quitters who disagreed that the health effects of smoking had been exaggerated provides affirmation that smokers continued to be open to and likely to be influenced by this kind of advertising strategy. Although others have criticised fear appeal approaches, ${ }^{11}$ Donovan and Henley argue that threat (or negative) appeals are more appropriate than incentive (or positive) appeals for many health issues, ${ }^{23}$ particularly for the cessation of undesirable behaviours. Furthermore, Biener and colleagues find that graphic messages that "tell the truth" about tobacco are favourably appraised by both adults and teenagers. ${ }^{24-26}$ In one study, Biener found that adverts eliciting strong emotion, such as sadness and fear, were rated by smokers and nonsmokers as most effective, whereas humorous entertaining adverts were rated as least effective. ${ }^{26}$ These findings are consistent with the review of Witte and Allen, ${ }^{16}$ who concluded that fear arousing messages can be effective, if supported by information about ways to minimise the threat.

The findings pertaining to advertising recall, recognition, appraisal, new learning, and change in smoking related attitudes provide some degree of optimism for expecting to observe positive changes in smoking behaviour. Over the period coincident with the campaign, declines in smoking prevalence among Australian adults were observed. ${ }^{27}$ However, the extent to which the campaign, as opposed to other tobacco policy influences ${ }^{28}$ and secular trends, has contributed to change is difficult to apportion. Overall, these results are consistent with at least expecting there to be a positive influence on adult smoking behaviour.

\section{APPENDIX}

\begin{tabular}{|c|c|c|c|c|}
\hline \multirow[b]{2}{*}{ Percentage result } & \multicolumn{4}{|c|}{ Sample size (n) } \\
\hline & 500 & 700 & 1000 & 1500 \\
\hline $10 \%$ & $2.6 \%$ & $2.2 \%$ & $1.9 \%$ & $1.5 \%$ \\
\hline $20 \%$ & $3.5 \%$ & $3.0 \%$ & $2.5 \%$ & $2.0 \%$ \\
\hline $30 \%$ & $4.0 \%$ & $3.4 \%$ & $2.8 \%$ & $2.3 \%$ \\
\hline $40 \%$ & $4.3 \%$ & $3.6 \%$ & $3.0 \%$ & $2.5 \%$ \\
\hline $50 \%$ & $4.4 \%$ & $3.7 \%$ & $3.1 \%$ & $2.5 \%$ \\
\hline $60 \%$ & $4.3 \%$ & $3.6 \%$ & $3.0 \%$ & $2.5 \%$ \\
\hline $70 \%$ & $4.0 \%$ & $3.4 \%$ & $2.8 \%$ & $2.3 \%$ \\
\hline $80 \%$ & $3.5 \%$ & $3.0 \%$ & $2.5 \%$ & $2.0 \%$ \\
\hline $90 \%$ & $2.6 \%$ & $2.2 \%$ & $1.9 \%$ & $1.5 \%$ \\
\hline
\end{tabular}

\section{ACKNOWLEDGEMENTS}

This study was funded by the Commonwealth Department of Health and Aged Care. The design of the study and questionnaire were the responsibility of the Research and Evaluation Committee of the NTC, especially Ron Borland, Robert Donovan, and David Hill. We thank Irene Bobevski for assistance with statistical interpretation.

\section{DISCLOSURE}

Melanie Wakefield is a Senior Editor of Tobacco Control. She was excluded from editor-reviewer correspondence and was not involved in the editorial decision making process for this manuscript.

\section{Authors' affiliations}

M Wakefield, J Freeman, Centre for Behavioural Research in Cancer, The Cancer Council Victoria, Victoria, Australia R Donovan, Centre for Behavioural Research in Cancer Control, Curtin University, Western Australia

\section{REFERENCES}

1 Pierce JP, Dwyer T, Frape G, et al. Evaluation of the Sydney "Quit For Life" anti-smoking campaign. Med J Aust 1986;144:341-7.

2 Pierce JP, Macaskill P, Hill D. Long-term effectiveness of mass media led antismoking campaigns in Australia. Am J Public Health 1990;80:565-9

3 Wakefield M, Chaloupka F. Effectiveness of comprehensive tobacco control programmes in reducing teenage smoking in the USA. Tob Control 2000;9:177-86.

4 Centers for Disease Control and Prevention. Best practices for comprehensive tobacco control programs. August 1999. Atlanta, GA: US Department of Health and Human Services, Centers for Disease Control and Prevention, National Center for Chronic Disease Prevention and Health Promotion, Office on Smoking and Health, August 1999. www.cdc.gov/tobacco/bestprac.htm 
5 Institute of Medicine and National Research Council. State programs can reduce tobacco use. National Cancer Policy Board, Institute of Medicine, National Research Council and Board on Health Promotion and Disease Prevention, Institute of Medicine. Washington, DC: National Academy of Sciences, February 2000. http:// books.nap.edu/html/state_tobacco

6 Wakefield $M$, Flay B, Nichter $M$, et al. Effects of anti-smoking advertising on teenage smoking: a review. J Health Comm 2003:8:229-47.

7 Popham WJ, Potter LD, Bal DG, et al. Do anti-smoking media campaigns help smokers quit? Public Health Rep 1993;108:510-3.

8 Pierce JP, Gilpin EA, Emery SL, et al. Has the California Tobacco Control Program reduced smoking? JAMA 1998:280:893-9.

9 Biener L, Harris JE, Hamilton W. Impact of the Massachusetts tobacco control programme: population based trend analysis. BM 2000;321:351-4.

10 McVey D, Stapleton J. Can anti-smoking television advertising affect smoking behaviour? Controlled trial of the Health Education Authority for England's anti-smoking TV campaign. Tob Control 2000;9:273-82.

11 Hastings G, MacFadyen L. The limitations of fear messages. Tob Control 2002;11:73-5.

12 Pechmann C, Reibling E. Planning for an effective anti-smoking mass media campaign targeting adolescents. J Public Health Manag Pract 2000;6:80-94.

13 Hill D, Chapman S, Donovan R. The return of scare tactics. Tob Control 1998;7:5-8

14 Biener L, Taylor TM. The continuing importance of emotion in tobacco control media campaigns: a response to Hastings and MacFadyen. Tob Control 2002;11:75-7

15 Sutton SR. Shock tactics and the myth of the inverted U. Brit J Addict 1992;87:517-9.

16 Witte K, Allen M. A meta-analysis of fear appeals: implications for effective public health campaigns. Health Educ Behav 2000;27:591-615.

17 Hill D, Carroll T. Australia's National Tobacco Campaign. Tob Control 2003;12(Suppl II):ii9-14.
18 Wakefield $M$, Freeman J, Boulter J. Changes associated with the National Tobacco Campaign: pre and post campaign surveys compared. In: Hassard K (ed). Australia's National Tobacco Campaign: evaluation report volume one. Canberra: Commonwealth Department of Health and Aged Care, 1999. www.health.gov.au/pubhlth/publicat/document/ metadata/tobccamp.htm

19 Tan N, Wakefield M, Freeman J. Changes associated with the National Tobacco Campaign: results of the second follow-up survey. In: Hassard K (ed). Australia's National Tobacco Campaign: evaluation report volume two. Canberra: Commonwealth Department of Health and Aged Care, 2000. www.health.gov.au/pubhlth/publicat/document/metadata/ tobccamp_2.htm

20 Wakefield $M$, Freeman J, Inglis G. Changes associated with the National Tobacco Campaign: results of the third and fourth follow-up surveys. Melbourne, Australia: Centre for Behavioural Research in Cancer, The Cancer Council Victoria (In press).

21 Donovan RJ, Boulter J, Borland R, et al. Continuous tracking of the Australian National Tobacco Campaign: advertising effects on recall, recognition, cognitions, and behaviour. Tob Control 2003;12(Suppl II): ii30-9.

22 Donovan RJ. Public health advertising: execution guidelines for health promotion professionals. Health Prom J Aust 1991;1:40-45.

23 Donovan RJ, Henley N. Negative outcomes, threats and threat appeals: towards a conceptual framework for the study of fear and other emotions in social marketing. Soc Market Q 1997;4:56-67.

24 Biener L. Adult and youth response to the Massachusetts anti-tobacco television campaign. J Public Health Manag Prac 2000;6:40-4

25 Biener L. Anti-tobacco advertisements by Massachusetts and Philip Morris: what teenagers think. Tob Control 2002;11 (Suppl II):ii43-6.

26 Biener L, McCallum-Keeler G, Nyman AL. Adults' response to Massachusetts anti-tobacco television advertisements: impact of viewer and advertisement characteristics. Tob Control 2000;9:401-7.

27 White V, Hill D, Siahpush $M$, et al. How has the prevalence of cigarette smoking changed among Australian adults? Trends in smoking prevalence between 1980 and 2001. Tob Control 2003;12(Suppl II):ii67-74.

28 Scollo $M$, Younie S, Wakefield $M$, et al. Impact of tobacco tax reforms on tobacco prices and tobacco use in Australia. Tob Control 2003; 12(Suppl II):ii59-66. 